\title{
SECURITY OF TENURE AT THE CROSSROAD OF CONFLICTING INTERESTS: THE BRUSSON FINANCE (PTY) LTD SAGA*
}

\section{$1 \quad$ Introduction}

Section 26 of the South African Constitution of 1996 makes provision for the right to have access to adequate housing (right to housing) for everyone. The section further enjoins the State to devise measures within the availability of its resources, to progressively realise this right. This has led to the adoption/enactment and implementation of a number of statutes and policies such as the Housing Act (107 of 1997), the Breaking New Ground of 2004, the Upgrading of Informal Settlement Programme of 2004, the National Housing Programme for Housing Assistance in Emergency Housing Circumstances of 2004, the National Housing Code of 2009 and the Outcome 8 Delivery Agreements: Sustainable Human Settlements and Improved Quality of Household Life of 2010 . In passing, adopting and implementing these statutes and policies, the Government is discharging its obligations under section 26 of the Constitution to provide housing to all citizens.

However, the effort of the state to fulfil its constitutional mandate to realize the right to housing is under severe threat following the Brusson Finance (Pty) Ltd matter which I refer to as "saga" (hereinafter "Brusson"). The Brusson saga refers to a number of people who were fraudulently deprived of their property (used a guarantee) as a result of a well-orchestrated scam offering credit facilities to those with bad credit records who could no longer receive credit facilities from financial institutions. As a result of such fraudulent deprivation of their property, two of the victims launched proceedings to recover their property. That case (Matile Joseph Ditshego, Lizzie Ditshego \& National Credit Regulator $v$ Brusson Finance (Pty) Ltd, Amanda Boshoff, Absa Bank \& The Registrar of Deeds (5144/2009) [2010] ZAFSHC 68 (hereinafter "the Ditshego case") and the subsequent one analysed below, are used only to illustrate the Brusson mechanism and difficulties encountered by victims to get back their property. (Yvonne Bella Nkosi v Brusson Finance (Pty) Ltd yet unreported (the liquidation case). Furthermore, there are other decided cases (Cloete NO v Basson (61907/09) [2010] ZAGPJHC 87 (4 October 2010; Nedbank Limited $v$ Mosebo Richard Tladi and Mthombeni Sindiswa case no 39356/2010 (SG) (on 25 January 2011, the court per Moshidi $\mathrm{J}$ granted summary judgment in favour of the plaintiff in terms of which the defendants were, amongst others, ordered to pay jointly and severally, the sum of R167 733,43 and the defendants' property ERF 8575

\footnotetext{
The author was involved in the Brusson matter during his internship at the Legal Resources Centre in 2010 where he encountered the desperation of a number of people who lost their property which represented the only thing evidencing their life achievement. The author is indebted to Ms Nomfudo Gobodo, former Director of LRC Johannesburg for involving him in the matter.
} 
Dobsonville Extension 2 Township was declared executable). In Nedbank Limited $v$ Mosebo Richard Tladi and Mthombeni Sindiswa (case no $38391 / 2010(\mathrm{JHC})$ ), where a similar order was also granted (on 25 January 2011) against the defendant's to pay the sum of R545 787,52 and the execution of the defendants' property ERF 543 Finsbury Township. In Nedbank Limited v Mugeri Mashudu Ruth and Mugeri Tshilidzi Vincent (case no 37497/2010 (JHC) on 2 November 2010), the court per Wepane J ordered the defendants, amongst others, to pay jointly and severally, the sum of R566 603,34, and the defendants' property ERF 1 Monaheng Township was declared executable (hereinafter "Nedbank cases"). Some other cases are likely to be lodged, all in connection with Brusson, hence the word "saga". These cases serve only as a point of departure for this note, and comments made thereto go beyond the scope of the judgments. These comments are extended to the Brusson scheme in general and should not in any way, be constrained or limited to the findings of the court. In other words, the comments are not against the findings of the courts. The Brusson saga resuscitates the debate of the horizontal application of the Bill of Rights to private disputes when a violation of a constitutional right may be invoked by either party. This necessitates the granting of remedies other than those provided for by the relevant statutes when such remedies would not suffice to satisfactory remedies to all the parties. Unless such remedies are granted to salvage the situation, many beneficiaries from the Brusson scam will be left homeless (if not already) in the near future, thereby curtailing Government effort to provide security of tenure and reduce homelessness countrywide. In order to understand the difficulties and complexities encountered by all parties (court, liquidators and the National Credit Regulator) to transfer properties back to the original home owners, I provide an in-depth mechanism of the Brusson's scheme.

\section{Brusson scheme}

Brusson was a company duly registered and incorporated in terms of the company legislation of the Republic of South Africa, having its principal place of business at 37 Vorster Avenue, Glenanda, Johannesburg. Brusson was part of a property group that specialized in all aspects of the residential property market, such as development, marketing, finance, investment and construction (http://www.brussonfinance.co.za (accessed on 2010-08-04) website no longer available as the company is under liquidation). One of Brusson's objectives was to help people with a blemished credit record to obtain finance, provided that they are property owners and meet the general borrowing criteria. It is important to note that Brusson's clients comprised mostly of blacklisted persons who could not get financial assistance from any financial institution.

\section{Brusson's mechanism}

The scheme operated as follows:

- Clients would approach Brusson to request or to apply for a loan and Brusson would contact a third party called the "investor", with a good credit record to purchase the clients' property without the clients' knowledge and 
consent. Two things warrant explanation in order to clarify the scheme. Firstly, at all material times, home owners' understanding of the loan agreement was that their properties were to be used as security for the loan. Home owners were never fully aware of the true nature and the extent of the terms of the agreements. Put differently, home owners knew that they were applying for short-term loans in respect of which their properties would serve as security. Secondly, "investors" got involved in the business through an advertisement which promised them extra income if they joined the scheme. Unlike clients, "investors" were informed that their credit worthiness will help them get a loan from the bank against a property to be transferred in their names and in return, would receive a monthly fee until the home owners settle their loan.

- The property will later be registered into the name of the "investor", subject to the application of a tri-parte agreement concluded with all the parties.

- Brusson then used the credit record of the "investor" to obtain a loan from a financial institution on behalf of the "investor" and pay off any existing outstanding bond together with any ancillary debt relating to the levies payable on the property.

- Immediately upon registration, the "investor" sells the property back to the clients (who are the original home owners) through a standard sale by way of an instalment-sale agreement, which was in compliance with the Alienation of Land Act 68 of 1981. The repurchase price was arrived at by adding $25 \%$ (for Brusson's fee) to the conduit-sale price.

- The client was then obliged to pay over a monthly amount (described as rent in the agreements) to Brusson which was far in excess of what was necessary to service the original bond the clients had (for those properties that initially had a mortgage bond). The reason why the monthly payments were far in excess of what was necessary to service the original bond is because this included monthly payments for Brusson and the "investor".

- Even though the client had bought his property back, transfer of the property back into the client's name will only take place once the conditions of the deed of sale contract have been fulfilled. These conditions are: the funds used to cancel the initial bond (for those properties that initially had a mortgage bond), interests on the loan, administration fees and other incidental costs.

- During the existence of the agreements, Brusson was the administrator of all the transactions, received all monies payable by the clients to the "investor" which included fees payable to Brusson and payment of the bond.

\section{Documents used in the scheme}

The documents that formed part of the scheme and for which the clients had to sign were: 


\section{The offer to purchase}

This was an agreement in terms of which, Brusson's clients were the sellers of their property to an unknown purchaser who was the "investor". Brusson's clients were the first to sign this agreement. The purchase price was fixed by Brusson after evaluation of the property and Brusson's clients had to bear the cost of the transfer of their property to the unknown purchaser.

\section{The memorandum of agreement}

It was an agreement signed between Brusson, a first party and a second party. In this agreement, the first party was referred to as the "investor, the second party the home owner. It stated that Brusson would manage the agreement and all financial issues related to the agreement. It defined the first agreement as the offer to purchase in terms of which Brusson's clients sold their property to the "investor". In this agreement, Brusson's clients acknowledged that they were not credit worthy and that they had exhausted all avenues to get a loan. They also consented to the fact that Brusson was incurring financial risk in standing surety for them and to a monthly payment determined by and paid to Brusson (see in this regard, section 2.3 of the memorandum of agreement which provides that the second party acknowledges that Brusson has incurred huge financial risks in standing surety for the second party's obligations). Section 3.1 provides that in the event that the home owner fails to pay the monthly bond instalments, rates and taxes, Brusson guarantees the payment so that the investor will not be prejudiced.

\section{The memorandum of understanding}

This memorandum was entered into between Brusson and its clients. This agreement stated that transfer and registration fees, a certain amount towards future rates and taxes, an amount to cover the attorney fees to cancel the initial bond and an amount to cover the first and second valuation of the property were to be deducted from the proceeds of the initial sale.

\section{The deed of sale}

This was signed between Brusson's clients as second party and an unknown first party who was an "investor". In terms of this agreement, the first party agreed to sell to Brusson's clients, their property at a fixed purchase price payable in monthly instalments. This instalment was the same amount agreed upon in the memorandum of agreement.

The reason why I say "unknown first party" and "unknown purchaser" is because when the clients sign the deed of sale and the offer to purchase, the space reserved for the first party in the deed of sale for instance is left blank. But this space will later be filled by the "investors". One feature of the scheme which warrants mentioning is that all parties in the scheme sign a power of attorney to Brusson's lawyer who will later sign on behalf of both the investor and clients, the necessary documentation. As a result of the Brusson's scheme, some of the clients' properties who did not have bonds registered 
over their properties, found themselves with relatively large bonds which they were unable to service while others who had small existing bonds, found themselves with new bonds of higher value. Most of Brusson's clients received an amount lesser than the loan amount requested. No explanation would be given, but they would still be expected to pay the agreed instalment. It is estimated that some 1000 people have fallen victim to the so-called "reverse mortgage" scheme (as per the author's telephonic discussion with the liquidators on 7 December 2010). In order to illustrate the above mechanism, I briefly provide the facts of the Ditshego case.

\section{The Ditshego case}

The first and second applicants owned property in Soweto in which they lived. They had cash-flow problems to the extent that their car, which they bought through an instalment-sale agreement, could be repossessed for failure to pay certain instalments on the said car. Because they were blacklisted, they could not obtain a loan from recognized financial institutions. They needed approximately R40 000,00 to pay off the balance on the said car. They approached Brusson for a loan subsequent to an advertisement of Brusson in a newspaper inviting home owners in need of finance to get in touch with Brusson regardless of their credit record. They got in touch with Brusson's office and spoke to Jabu. They informed Jabu that they needed a loan of approximately R40 000,00 . They also informed Jabu that they owned property valued at around R260 000,00 subject to a bond of some R94 000,00 in respect of which they paid a monthly instalment of approximately R1 200,00. They provided details regarding the property, the outstanding balance of the bond and their personal details needed by Jabu to establish the value of the property. Some two days later, Jabu phoned the first applicant and indicated that the value of the property according to Brusson stood at $\pm R 270000,00$. They were further informed that Brusson would pay approximately $\pm R 102$ 000,00 to Absa Bank, the third respondent, to cancel the existing bond and the balance of R168 000,00 to be paid to the applicants.

They later received certain documentation from Brusson which they did not agree with and telephoned Jabu who reassured them that "nothing has changed" and that they would receive an amount of R168 000,00. They also informed Jabu that they did not want to sell their house. Jabu informed them that they were not doing that but that their house would serve only as security for the loan. Based on these assurances, the applicants signed four documents as explained above consisting of a blank offer to purchase, a blank deed of Sale, a memorandum of understanding between the applicants and Brusson and a memorandum of agreement between the applicants, Brusson and the investor. It later came to their attention that the money paid to cancel their existing bond came from the R168 000,00 and not in addition thereto as they had initially thought and that the monthly instalment of R2 827,12 represented the rent due to their occupation of their own property. Brusson paid a total amount of R123 109,53 divided as follows: R24 109,53 deposited into the applicants' bank account; R93 135,00 which was rounded off to R94 000,00 for the settlement of the .existing bond and R5 000,00 representing rates and taxes. 
They approached the National Credit Regulator (NCR) who investigated the matter and lodged proceedings before the Free State High Court in Bloemfontein. The High Court ruled that all the agreements concluded by Brusson and the applicants were illegal and void on two grounds. Firstly, the court held that the whole scheme amounted to a pactum commissorium in that the real intention of the applicants was to obtain a loan from Brusson against security of their property, and that all the agreements concluded were simulated transactions. Secondly, the court held that all transactions were unlawful because Brusson was not a registered credit provider as contemplated by the National Credit Act 34 of 2005 (NCA). The court further ordered the transfer of the applicants' property back to them.

\section{The Liquidation case}

Subsequent to the Ditshego case of 22 July 2010, one "investor", Yvonne Bella Nkosi, approached the North Gauteng High Court for a provisional liquidation of Brusson which was eventually granted on 3 August 2010. On 14 September 2010, the court ordered the liquidation of Brusson and confirmed the appointment of CM Cloete and AP Oliveira of Xirimele Trustees SA (Pty) Ltd as the liquidators. The liquidation process is still pending in court with a return date being 7 May 2012, where 24 respondents were joined to the main application and ordered to file opposing affidavits.

\section{$5 \quad$ Some comments}

As stated above, the comments are not limited to the two cases discussed earlier but are extended to the Brusson's scheme as a whole. Although the responsibility of the third respondent (Absa Bank) was not an issue in the Ditshego case, it is argued in this article that had a proper assessment of Brusson's activities by Absa bank in the Ditshego case and all financial institutions in other related cases been conducted, this "saga" would have been avoided. This is due to the fact that, although the "investors" applied for the loan, the money was deposited into Brusson's account. Moreover, Brusson was the one managing all the funds and paying all instalments. This should have alerted the banks to the fact that a single entity was at the centre of all transactions emanating from different mortgages on different properties. This brings me to first explore the National Credit Act 34 of 2005 and its relevance to the assessment of potential consumers.

\section{The National Credit Act and reckless lending}

The NCA was enacted by virtue of section 3(c)(i)-(ii) and (g) for the purpose of: promoting responsibility in the credit market by encouraging responsible borrowing; avoiding over-indebtedness; fulfilling financial obligation by consumers; discouraging reckless credit-granting by credit providers and contractual default by consumers; addressing and preventing overindebtedness of consumers and providing mechanisms for resolving overindebtedness based on the principle of satisfaction by the consumer of all responsible financial obligations. For the purpose of our discussion, I shall limit myself to section 80 of the NCA which provides that a credit agreement is 
reckless if at the time the agreement was made, the credit provider failed to conduct an assessment of the potential consumer. This section should be read in conjunction with section 81 of the NCA which formally prohibits any credit provider from entering into a credit agreement without taking reasonable steps to assess the potential consumer-debt repayment history and his or her general understanding of the risks and costs of the proposed credit agreement. The assessment of the prospective consumer is twofold. Firstly, the credit provider must advise and inform the consumer of the risks, rights and obligations that are consequential to the credit agreement so that he or she must understand the extent of the credit agreement (see Vessio "Beware the Provider of Reckless Credit" 20092 TSAR 279 280). Secondly, the credit provider must take reasonable steps to assess the consumer history as a consumer under credit agreements as well as the consumer's existing financial means, prospects and obligations, and whether there is a reasonable basis that the intended commercial activities of the consumer will be successful (see s 81(2) of the NCA; Vessio 20092 TSAR 280; and Stoop "South African Consumer Credit Policy: Measures Indirectly Aimed at Preventing Consumer Over-Indebtedness" 200921 SA Merc LJ 367). The prospective consumer must fully and truthfully answer any requests for information made by the credit provider as part of the assessment process, failing which the credit provider is entitled to raise a defence for reckless lending (section 81(1) and (4) of the NCA). In summary therefore, a credit agreement is reckless if the credit provider:

(i) fails to conduct a proper assessment irrespective of what the outcome of such assessment might have been, or

(ii) conducts an assessment but concludes an agreement despite the fact that the information available indicated that the consumer did not generally appreciate or understand the risks, costs or obligations involved or would over-indebt himself or herself into that agreement (see Otto and Otto The National Credit Act Explained 2ed (2010) 77; Vessio 20092 TSAR 280; Stoop 200921 SA Merc LJ 368; and Stoop and Louw "The National Credit Act Regarding Suretyships and Reckless Lending" 2011 PER/PELJ 87/226).

Vessio warns that the concept of reckless lending will inevitably have an element of over-indebtedness which is present to almost all credit agreements. A consumer is over-indebted if by virtue of the information available at the time the determination is made, the consumer will be unable to discharge all the obligations under the credit agreements which the consumer is already servicing, taking into account the financial means, prospects of the consumer and obligations and probable propensity to satisfy timeously all the obligations under all the credit agreements to which the consumer is party as indicated by the consumer's history-debt repayment (s 79 (1)(a) and (b)).

Having stated the legal position with regard to reckless lending, this article argues that financial institutions had failed to conduct an assessment on the so-called "investors" in the Brusson's scheme. Some of the "investors" held several mortgage bonds over different properties located in different geographic areas and other debts at the time within the same financial institution. It is a requirement of the NCA that credit providers must assess 
any prospective consumer, taking into account amongst others things, his/her financial means, prospects and obligations. Section 79(3) of the NCA defines financial means, prospects and obligations as income, or any right to receive income, regardless of the source, frequency or regularity other than income that the consumer receives or has a right to receive or holds in trust for another person. The definition also includes the financial means, prospect and obligations of any other adult person within the consumer's household to the extent that the consumer and such adult share their respective financial means and mutually bear their respective financial obligations.

If a proper assessment had been carried out, the banks would have been aware that the "investor" to whom a property was being transferred to had existing financial obligations (cars on instalment, house/houses, etc ...). A consultation with two "investors" revealed that one had four houses and the other two houses registered in their respective names (although it may be argued that the number is insufficient to draw a conclusion, this nevertheless illustrates and supports my argument). A proper investigation would have revealed that their respective income could not allow them to be eligible for any further loan for the purchase of the litigious houses. A proper assessment would have established that their financial means could not satisfy all their existing credit agreements. The consultation with one of the "investors" with four properties registered in his name revealed that the two partners' financial means (combined income) were insufficient to satisfy all the existing obligations they had under all their credit agreements prior to entering into the last credit agreement. Moreover, it is estimated that most "investors" had more than one property registered in their names. In some cases, some "investors" had up to seven properties (as per my telephonic conversation with Matthew, a candidate attorney from Legal Resources Centre (LRC) on 16 May 2012. The LRC is representing the original home owners and is also assisting "investors" to halt any proceedings against home owners). The rationale behind "investors" having many properties is to be found in the Brusson's scheme. In fact, the more houses "investors" had in their names, the more profit they would make. This implies that the amount of profits made by each "investor" depended on the number of properties he or she had in his or her name. The practice was to encourage "investors" to sign as many agreements as possible in order to increase profits. As a result, many of these "investors" are over-indebted and may be declared insolvent and even blacklisted (because they cannot afford the payment of all bonds which exceed their monthly income and also because many home owners have defaulted their payments. The only recourse they have is to sell the properties). It is in this respect that during the public comment debate over what was then the Bill, Levenstein rightly pointed out that as far as reckless lending was concerned, the NCA aimed to ensure that consumers were not drawn into applying and agreeing to borrow money when they would be unable to service the credit and became over-indebted (Levenstein "Setting New Parameters for Reckless Lending" 2006 Without Prejudice 50). He cautions that past practices in South Africa which consisted in according easily too much credit facilities to many people with little money should stop with the coming into force of the NCA, failing which many credit providers will be found guilty of reckless lending under the new NCA. Levenstein's call unfortunately fell on deaf ears. Pursuing their past lending practices, the banks have been giving credit facilities to potential consumers without 
properly assessing the financial means of prospective consumers. In this context, the so-called "investors" in the Brusson's scheme received credit facilities without proper assessment by the credit provider to establish whether their financial means could satisfy their credit agreements. By so doing, they fell short of the requirement of the NCA which prohibited reckless lending and put the burden of responsibility squarely in the camp of the lenders (Whitfield "Tough Times Ahead for the NCR: Legislation Provides Strong Framework but Implementation Fraught with Problems" 2007 Finweek 20-21).

Having established that banks have failed to conduct an assessment in terms of the NCA, they are therefore guilty of reckless lending. By virtue of section 83 of the NCA, when a court finds that a credit agreement is reckless due to the fact that the credit provider has failed to conduct an assessment or where such assessment was conducted but the credit provider entered into the agreement despite the fact that from information gathered, the consumer did not understand or appreciate the risks, costs, or obligations under the agreement, the court may make an order to suspend the force and effect of the credit agreement until a date determined by the court, or set aside all or part of the consumer's obligations and rights under that credit agreement. It is, however, submitted that, since the NCA does not expressly state that reckless credit renders illegal or unlawful a credit agreement therefore null and void, such credit agreement remains valid until the court decides its fate in respect of the consequences as provided for in the NCA (Van Jaarsveld "Some Observations Regarding Reckless Lending Credit in Terms of the National Credit Act 34 of 2005" 201073 THRHR 651). Levenstein has warned of the devastating effects that the granting of reckless lending will have on credit providers who are found guilty. One of these effects is to set aside all or part of the obligations of the consumer. Van Jaarsveld argues, however, that, despite being empowered to set aside all or part of the rights and obligations of the consumer, section $83(2)(a)$ of the NCA is silent when it comes to restoration. The difficulty she finds with the section is whether the credit provider will still be able to reclaim any credit granted to the consumer or whether the consumer could still reclaim any payment made by him or her to the credit provider. She is of the opinion that the section does not prohibit the credit provider from claiming credit granted in terms of another cause of action such as unjustified (Van Jaarsveld 201073 THRHR 653).

Another affect is the suspension of a credit agreement which the court must order when the consumer would be over-indebted as a result of reckless lending. According to Van Jaarsveld, the effect of the suspension of a credit agreement is to create "a moratorium period during which the consumer" does not make any payment under the agreement and "no interest, fee or other charge under the agreement may be charged to the consumer" (Van Jaarsveld 201073 THRHR 654). In respect of the credit provider, the affect of a suspension order is that its rights under the credit agreement are unenforceable against the consumer. However, Van Jaarsveld questions the wisdom of the NCA which provides a lenient sanction of suspension for a credit agreement which causes consumer over-indebtedness because the consumer remains indebted towards the credit provider despite the suspension order (Van Jaarsveld 201073 THRHR 654).

With regard to the Brusson saga and in the Ditshego case in particular, I am of the opinion that, although the court ordered transfer of the property 
back to the original owners, no weight was attached to the role of the banks in this saga for failing to assess both Brusson and the "investors". It is my submission that, although the issue of reckless lending was not before the court, given that the matter is now handled by the Hawks, any solution that excludes the responsibility of financial institutions is bound to fail. This is because despite more than two of proactive litigations, all parties are still in the impasse as home owners are evicted or threatened with eviction and banks are getting court orders for the execution of properties as evidenced by the Nedbank cases referred to above. This brings me to the issues of security of tenure which lie at the centre of this article.

\section{Security of tenure in South Africa}

Security of tenure is a critical aspect of South African land history that the Constitution aims to address. This is expressed in section 25 of the Constitution which provides inter alia that, no one may be deprived of his or her property except in terms of law of general application, for public interest and subject to compensation (see Roux "Property" in Woolman, Bishop and Brinckhill Constitutional Law of South Africa 2ed (2010) 46-28). This should be understood in the history of dispossession of blacks of their properties characteristic of the colonial conquest and later by the apartheid regime (Van der Walt "Property. Social Justice and Citizenship: Property Law in PostApartheid South Africa" 20083 Stell LR 325-346). Property may be acquired through credit facilities obtained from credit providers, inheritance, or State's intervention. It is the last one which is the subject matter of this article. (For an understanding of the constitutionality of the property clause, see Currie and De Waal The Bill of Right Handbook 5ed (2005) Chapter 25; and Freedman "The Constitutional Right not to be Deprived of Property: The Constitutional Court Keeps its Option Open" 20061 TSAR 83-100.)

The new Government led by the African National Congress undertook to provide security of housing to all. This was expressed in the White Paper on housing (of 1994 5.3.3.) which affirms that security of tenure is a key cornerstone of Government's approach towards providing housing to people in need. To this end, the Government has passed legislation and adopted policies which provide housing subsidies for a household earning below a certain threshold. The Breaking New Ground restructured the subsidy scheme by extending credit and savings linked subsidy for households falling within the income category R3 501,00 to R7 000,00 per month in order to enable these medium-income earners to secure a home. The question raised by the Brusson saga is how to balance the interests of banks and house owners who have secured their tenure through Government intervention in fulfilling its constitutional obligation to provide access to housing to everyone. It is clear that many former home owners have received their property through State's subsidies.

The case has become complicated with the liquidation of Brusson two months after the Ditshego case which was not anticipated by all parties. With this new scenario, the rules of the law of insolvency shall apply. It is my submission that, since home owners can no longer exercise their right directly against Brusson as a result of the liquidation, their security of tenure is threatened mainly because financial institutions, which I argue, are guilty of 
reckless lending, will have preferential payment over these home owners. This unfortunate situation impedes on the effort of Government to provide the right to access to adequate housing by virtue of the constitutional provision encapsulated in section 26 of the Constitution.

In terms of section 2 of the Insolvency Act (24 of 1936), financial institutions fall within the category of secured creditors (see Bertelsmann, Evans, Harris, Kelly-Louw, Loubser, Roestoff, Smith, Stander and Steyn Mars: The Law of Insolvency in South Africa 9ed (2008) 432-466). Therefore, they enjoy preferential payment over other creditors in the realisation of Brusson's estate. Original home owners are categorized as unsecured creditors and will therefore in concurrence with other non-preferential creditors, be paid after preferential creditors have received payment. This is an unfortunate situation that will leave many people homeless. Some of these former home owners as mentioned above, have been evicted from their homes by Brusson, the banks or the "investors" while others are living under constant threat of eviction. This is a considerable setback to Government effort to realize the right to housing to people.

Having argued that banks are liable for reckless lending, this article posits that these former home owners who had been unlawfully dispossessed of the ownership of their properties, may invoke the violation of their constitutional right to have access to housing in order to restore their security of tenure. (See also the Prevention of Illegal Eviction from and Unlawful Occupation of Land Act 19 of 1998 which was enacted to give effect to section 26(3) of the Constitution. Of particular importance are sections 4 (2) and 6. See also City of Johannesburg Metropolitan Municipality v Blue Moonlight Properties 39 (Pty) Ltd 2012 (2) BCLR 150 (CC), where the court ordered the eviction of the unlawful occupiers subject to the provision of alternative accommodation by the city of Johannesburg. See also Occupiers, Shulana Court 11 Hendon Road Yeoville Johannesburg $v$ Steele 2010 (9) BCLR 911 (SCA). The home owners may rely on the decision of the Constitutional Court in Jaftha $v$ Schoeman, Van Rooyen $v$ Stoltz 2005 (1) BCLR 78 (CC) which was of the view that the sale in execution of a state-subsidized house of an indigent debtor constitutes a limitation of his or her section 26 rights.) Subsequent to the Jaftha case, Van de Walt (supra) comments as follows (332):

\begin{abstract}
"Whilst acknowledging the importance of protecting commercial interests the courts remain alert to the possibility that section 26(1) rights might be threatened by execution procedures. The balance between the two sets of interests is then established by expecting that potentially negatively affected homeowners should raise and prove the existence of a threat to their section 26 rights, whereupon the courts must consider the justification of allowing execution in view of all the circumstances" (Van der Walt 20083 Stell LR 332).
\end{abstract}

Reliance can also be made on the case of Absa Bank Ltd v Ntsane (2007 (3) SA 554 (T) 82-83), where the court did not allow a mortgagee to enforce an acceleration clause in the credit-loan agreement and refused to order the sale of execution of the property in that such execution would be an unjustifiable infringement of the defendant's right to have access to adequate housing and might constitute a violation of their right to dignity. The court had the following to say: 
"It is clear that it would be in conflict with s 26 of the Constitution to enforce the right to execute against immovable property and thereby terminate defendant's right to adequate housing [and that] ... to allow such a result in a country where housing is at a premium and poverty and the legacy of a previous dispensation deny millions the fundamental right to a roof over their heads infringes the fundamental right to adequate housing and may also, as was argued by Mr De Villiers, be in conflict with the right to dignity."

It is my submission that the sale in execution of a property pursuing a mortgage is unjustifiable if the poor debtor does not have alternative accommodation and will be homeless as a result of the eviction due to the sale in execution of his or her property; most importantly, since these debtors would no longer be eligible for state housing. Therefore, any eviction subsequent to any sale in execution of any state-subsidized house is a limitation of the right to have access to housing couched in section 26 of the Constitution. I find support in the recent Constitutional Court's judgment of Gunwana v Steko Development CC (2011 (8) BCLR 792). The key question in this case is whether section 27A of the Supreme Court Act and rule 31(5) of the Uniform Rules of Court are unconstitutional in so far as they allow the Registrar of the High Court to grant an order declaring immovable property executable. The Court found that the willingness of mortgagors to put their homes forward as security for the loans they acquire is not by itself sufficient to permit the Registrar to grant an order declaring immovable property executable without judicial oversight (par 41). The court further held that:

"It is true that a mortgagor willingly provides her immovable property as security for the loan she obtains from the mortgagee and that she thereby accepts that the property may be executed upon in order to obtain satisfaction of the debt.

But does that particular willingness imply that she accepts that

1. the mortgage debt may be enforced without court sanction;

2. she has waived her right to have access to adequate housing or eviction only under court sanction under section 26(1) and (3); and

3. the mortgagee is entitled to enforce performance, in the form of execution.

Mortgage bonds do not ordinarily contain clauses describing the purpose for which the mortgaged property is held by the mortgagor. The applicant's mortgage bond contains no such provision. To agree to a mortgage bond does not without more entail agreeing to forfeit one's protection under section 26(1) and (3) of the Constitution" (par 44 and 46).

The author also has support in the recent case of Moore $v$ Sheriff for the District of Vereening (case number 2013/18416) (subsequent to the Brusson saga) that the court is not prepared to grant the execution of properties. In that case, the South Gauteng High Court interdicted the first respondent from selling or disposing the applicants' properties.

Although one might argue with me in light of Standard Bank of South Africa v Hunkydory Investments 188 (Pty) Ltd (2010 (4) BCLR 374 (WCC)) that the execution of these properties will not violate anyone's constitutional right to housing, it is trite that the Constitutional Court, being the highest court in the land, the principle of stare decisis finds application. Mukundi states in this respect that, the effect of the Gunwana judgment is that it overturned the Supreme Court of Appeal's decision in Standard Bank of South Africa Ltd $v$ Saunderson (2006 (6) SA 262 (SCA)) and Nedbank Ltd v Mortinson (2005 (6) SA $462(\mathrm{~W})$ ) (Mukundi "Judicial Oversight for Sale in Execution of Residential Property" 201112 ESR Review 7). Having argued that home owners can 
invoke their constitutional right to oppose their eviction, I now propose how this right can be enforced against non-state actors in violation of their rights to engage in economic activity and derive profit from it.

\section{Enforcement of constitutional right against non-state actors}

It is trite that the Bill of Rights states expressly that a natural or a juristic person is bound by constitutional rights depending on the nature of the right and the duty in question. ( 8 of the Constitution. For a discussion about the horizontal application of the Bill of Rights, see Chirwa "The Horizontal Application of Constitutional Rights in a Comparative Perspective" 200610 Law, Democracy \& Development 21 48.) To this end, the horizontal application of the Bill of Rights makes it possible to enforce or to obtain redress of the violation of a constitutional right by non-state actors (departing from the general assumption that section 25 has no direct horizontal application between private actors (See Roux in Woolman et al Constitutional Law of South Africa 46-48). The recent case of Government Body of the Juma Musjid Primary School v Ahmed Asruff Essay NO (2011 (8) BCLR 761 (CC)) is illustrative to this effect. In this case, the Constitutional Court per Nkabinde $\mathrm{J}$ was to decide on the eviction of the school by the trustees, private entity owners of the building where the school operates. The court in interpreting the horizontal application of the Bill of Rights, had the following to say (par 58 and 60):

\footnotetext{
"It needs to be stressed however, that, the purpose of section 8(2) of the Constitution is not to obstruct private autonomy or to impose on a private party the duties of the state in protecting the Bill of Rights. It is rather to require private parties not to interfere with or diminish the enjoyment of a right. Its application also depends on the 'intensity of the constitutional right in question, coupled with the potential invasion of that right which could be occasioned by persons other than the State or organs of State' ... the Trust does have a negative constitutional obligation not to impair the learners' right to basic education."
}

It is clear from the excerpt that private parties do have a duty towards the realization of the right to education. The same can be said of the right to have access to housing which was interfered with by the banks. Therefore, the eviction of original property owners from their homes is an interference with their right to housing expressed in section 26 of the Constitution. Although the Brusson saga is of a private nature, its implication goes far beyond the scope of private law. The eviction, and most importantly, the loss of ownership of properties acquired through State intervention in fulfilling its constitutional mandate are constitutional matters. In this respect, the granting of usual remedies provided by the Insolvency Act and the law of contract is insufficient to provide satisfactory relief. This calls for the fashioning of "new tools" in order to vindicate the violation of the constitutional right to have access to housing (see Fose v Minister of Safety and Security 1997 (3) SA 786 (CC) 69 ), where the court held that it has the responsibility to "forge new tools" and fashion innovative remedies in order to adjudicate the violation of a constitutional right). To this end, this article suggests that the constitutional rights to have access to housing must take preference to that of financial 
institutions which must bear the consequences of their being guilty of reckless lending.

This note suggests, as a last resort, the intervention of Government if the need arises. Government intervention should emphasize the need to uphold the constitutional right to access to housing as entrenched in the Constitution so that properties acquired through State-intervention programme should not be taken from their owners.

\section{Conclusion}

The Brusson saga is in turmoil (in an email dated 23 March 2012 addressed to one stakeholder, the liquidators acknowledge the complexity of the matter and state that "If the scheme is declared illegal and unlawful in totality as well as all the contracts concluded by Brusson Finance with 'Investors' and 'ex home owners', this may have serious consequences for Financial Institutions as well as the enforceability of the contracts between the parties") in that the usual judicial adjudication process may not be enough to remedy it, thus opening the debate regarding the horizontal application of the Bill of Rights. In essence, section 8(2) makes provision for avenues for enforcing obligations of non-state actors in connection to constitutional rights or obtaining redress for any infringement of these rights committed by private persons. Section 8(3) enjoins the court to apply the common law and or develop it to the extent that the legislation fails to give effective remedy to the violation of rights in question. The court may also rely on its discretionary power to grant appropriate relief as provided in section 38 of the Constitution. Having this in mind, and taking into consideration the fact that the Insolvency Act and the law of contract will not provide satisfactory remedy; this paper envisages a solution that goes beyond the rules of this legislation and incorporates elements of constitutional law. The case also offers the court an opportunity to test the enforcement of the National Credit Act in the country since the concept of reckless lending is new to the South African legal system with no precedent to rely on. The solution envisaged in this note, provides therefore possible room for the court whereby the constitutional right to have access to housing should have preference to all other interests. By so doing, the courts should depart from the procedural (for sale in execution) and economic consideration (banks interests) since the Brusson saga also affects the efficacy of Government's housing programmes and infringes on the constitutional right of the right to access to adequate housing.

CJ Tchawouo Mbiada

Researcher at the Labour Court and Labour Appeal Court of South Africa 